JOURNAL OF

French and Francophone Philosophy
REVUE DE LA

philosophie française et de langue française

\title{
Solidarity and the Absurd in Kamel Daoud's Meursault, contre-enquête
}

Sarah Horton

Journal of French and Francophone Philosophy - Revue de la philosophie française et de langue française, Vol XXIV, No 2 (2016) 286-303.

\author{
Vol XXIV, No 2 (2016) \\ ISSN 1936-6280 (print) \\ ISSN 2155-1162 (online) \\ DOI $10.5195 /$ jffp. 2016.733 \\ www.jffp.org
}

\section{(c) EY-NC-ND}

This work is licensed under a Creative Commons Attribution-Noncommercial-No Derivative Works 3.0 United States License.

\section{ULIS D-Sunt}

This journal is operated by the University Library System of the University of Pittsburgh as part of its D-Scribe Digital Publishing Program, and is co-sponsored by the University of Pittsburgh Press 


\title{
Solidarity and the Absurd in Kamel Daoud's Meursault, contre-enquête
}

\author{
Sarah Horton \\ Boston College
}

Kamel Daoud's recent novel Meursault, contre-enquête demands philosophical attention for its revisiting of the themes of solidarity and the absurd, both of which are central to Albert Camus's works. ${ }^{1}$ The premise is that Haroun, the brother of the Arab Meursault killed, who was named Moussa, tells his story to an unnamed person (identified only as "un jeune universitaire"2) in a bar. In the world of this novel, Meursault wrote and published L'Étranger (entitled L'Autre), ${ }^{3}$ as well as other works. ${ }^{4}$ From the first sentence of Daoud's novel, "Aujourd'hui, M'ma est encore vivante" 5 - a clear contrast to the first sentence of L'Étranger, "Aujourd'hui, maman est morte" 6 -it is evident that Haroun's narrative replies to Meursault's. In this paper, I argue that although the word "solidarity" does not appear in the novel, Daoud compels us to ask what it means to respond to the absurd by solidarity with others when most are fleeing from the absurd and few care about solidarity. I analyze the way in which Haroun is forced to confront the reality of the absurd and to discover his own resemblance to Meursault: both, it turns out, are murderers, and both are strangers to a society that refuses to acknowledge the absurd and that disregards solidarity. Although Haroun is replying to Meursault, the force of his reply will not lie in a greater correspondence with the facts. Rather, as I will show, the importance of his narrative lies in what he reveals about solidarity and the absurd. Daoud's novel brilliantly reminds us that we must live in solidarity with others even if they hate us for acknowledging the absurd, even though no one-not Meursault, not Camus, and not Haroun - can offer a final, certain account of how to do so. 


\section{Murder and the Rejection of Solidarity}

It is necessary to briefly consider Camus's understanding of the absurd and of solidarity before analyzing Daoud's treatment of these themes in Meursault, contre-enquête. Camus explains that "[1]'homme se trouve devant l'irrationnel. Il sent en lui son désir de bonheur et de raison. L'absurde naît de cette confrontation entre l'appel humain et le silence déraisonnable du monde."7 Neither human desires nor the world are the absurd; the absurd is the conflict between the human desire for happiness and for meaning and the world that is devoid of meaning and in which we must someday die. Camus calls for us to rebel against the absurd even though such revolt can have no objective meaning, and he maintains that a life of revolt is enough to satisfy: "Cette révolte donne son prix à la vie. Étendue sur toute la longueur d'une existence, elle lui restitue sa grandeur." 8 Happiness can be found through embracing life in defiance of the universe. In his later book L'Homme révolté, Camus calls us to respond to the absurd with a revolt that is solidarity, siding with our fellow men against the universe: "La révolte naît du spectacle de la déraison, devant une condition injuste ou incompréhensible. Mais son élan aveugle revendique l'ordre au milieu du chaos et l'unité au cœur même de ce qui fuit et disparaît." 9 The révolté understands that human life has no transcendent meaning, but he chooses to side with humans and their ultimately futile desires rather than siding with the universe by disregarding those desires and treating human life as meaningless. The révolté thus refuses murder. Camus explains that "[1]a solidarité des hommes se fonde sur le mouvement de révolte et celui-ci, à son tour, ne trouve de justification que dans cette complicité."10 One who is in solidarity with others stands against oppression, although the universe offers us no transcendent reason to do so.

With this background, let us now turn to the beginning of Meursault, contre-enquete. Haroun's complaint is not only that Meursault killed his brother but that Meursault told his version of the story with no regard for the Arab he killed. This disregard reveals itself in Meursault's failure to call his victim anything but "l'Arabe." As Haroun explains, "Dès le début, on comprenait tout: lui, il avait un nom d'homme, mon frère celui d'un accident. Il aurait pu l'appeler 'Quatorze heures' comme l'autre a appelé son nègre 'Vendredi.' [...] Quatorze heures, c'est bien. Zoudj en arabe [...]."11 The notion of giving the dead man a name did not even occur to Meursault because he was preoccupied with his own sense of the absurd, which isolated him rather than leading him to solidarity with others. Haroun summarizes Meursault's exclusive focus on the absurd in his own life:

C'est le Français qui y joue le mort et disserte sur la façon dont il a perdu sa mère, puis comment il a perdu son corps sous le soleil, puis comment il a perdu le corps d'une amante, puis comment il est parti à l'église pour constater que son Dieu avait déserté le corps de 
l'homme, puis comment il a veillé le cadavre de sa mère et le sien, etc. ${ }^{12}$

The Arab's death becomes a mere side detail with little ultimate importance to the story of Meursault's confrontation with a society that seeks in God a refuge from the absurd, and it is this neglect of Moussa's death, more even than the murder itself, that angers Haroun. He exclaims, "Bon Dieu, comment peut-on tuer quelqu' un et lui ravir jusque sa mort? C'est mon frère qui a reçu la balle, pas lui! [...] Personne, même après l'Indépendance, n'a cherché à connaître le nom de la victime, son adresse, ses ancêtres, ses enfants eventuels."13 He suggests, moreover, that he knows the absurd better than Meursault ever did: "L'absurde, c'est mon frère et moi qui le portons sur le dos ou dans le ventre de nos terres, pas l'autre."14 Meursault was a French colonizer who lived in a country not his own without realizing that he had allied himself with the universe against his Algerian fellow men. The French treated Haroun and Moussa as strangers in their own land, and now that Algeria is independent, Haroun and Moussa himself remain alienated from Moussa's death, for not even his countrymen have thought to ask about the Arab's life. Moussa was excluded from his own story by a stranger concerned only with the absurd and with himself, and that is the true absurdity. Haroun suggests that Meursault has no right to be admired as a prophet with insight into the absurd, for he rejected solidarity and sided with the universe against his fellow men when he murdered Moussa-and again when he refused his victim a name.

The reasons for Haroun's anger are clear, and an examination of L'Étranger confirms the injustice of Meursault's actions. Meursault's neighbor, Raymond Sintès, asks him to write a letter to his mistress, who was cheating on him, to bring her back to him so that he can punish her. ${ }^{15}$ Meursault agrees: “je me suis appliqué à contenter Raymond parce que je n'avais pas de raison de ne pas le contenter." 16 After Raymond punishes his Arab mistress, he asks Meursault to testify that she had cheated on him so that he will not be punished for beating her, and Meursault again agrees. ${ }^{17}$ Later, at the beach, Raymond recognizes one of the two Arabs present as the woman's brother, ${ }^{18}$ who had been following him before. ${ }^{19}$ The brother injures Raymond,20 who then returns to the beach with Meursault. Meursault shows a willingness to kill: he tells Raymond, "'Mais s'il ne sort pas son couteau, tu ne peux pas tirer'" 21 and then says, "'Prends-le d'homme à homme et donne-moi ton revolver. Si l'autre intervient, ou s'il tire son couteau, je le descendrai."'22 Meursault seems here to have some sense of honor, as he insists that Raymond must fight with his hands if the Arab does not draw his knife, but he accepts that Raymond wants to start a fight with a man who is not attacking, and he feels no repugnance at the possibility of killing a man who wants to avenge his sister's abuse at Raymond's hands. The Arabs leave, but Meursault returns to the beach alone and sees the Arab who is the woman's brother; the Arab draws his knife, and Meursault shoots 
him. ${ }^{23}$ Note that the woman is another nameless Arab that Meursault wrongs, and if he had not written the letter, the confrontation at the beach would never have happened.

Let us now return to Daoud's novel and consider Haroun's account of the woman's story and of the murder. Haroun asserts, "Précisons d'abord: nous étions seulement deux frères, sans sœur à mœurs légères comme ton héros l'a suggéré dans son livre." 24 He concludes that the woman was Moussa's mistress and proposes an account of the murder accordingly:

Peut-être était-elle, après tout, l'une de ses passions. Je me suis toujours dit que le malentendu provenait de là: un crime philosophique attribué à ce qui, en fait, ne fut jamais rien d'autre qu'un réglement de comptes ayant dégénéré. Moussa voulant sauver l'honneur de la fille en donnant une correction à ton héros, et celui-ci, pour se défendre, l'abbattant froidement sur une plage. Les nôtres, dans les quartiers populaires d'Alger, avaient en effet ce sens aigu et grotesque de l'honneur. ${ }^{25}$

The "peut-être" indicates that he is not sure that the woman was one of his brother's lovers. He attributes to her the name "Zoubida," but in truth he does not know her name or even if she existed: "La femme mystérieuse! Si tant est qu'elle ait existé. J'en connais seulement le prénom; je suppose que c'est le sien, mon frère l'avait prononcé dans son sommeil, cette nuit-là. Zoubida. La nuit d'avant sa mort." 26 Zoubida may have been one of Moussa's mistresses but not Raymond's, or she may have existed only in Moussa's dream. The facts are obscure, and the story of Zoubida (even if she existed and was the woman in question) does not permit a clear moral either. One might point out that if the woman existed, then however "grotesque" his sense of honor was, Moussa at least stood in solidarity with her, unlike Meursault, who saw no reason to not help Raymond punish her. Note, however, that in the conflict between Raymond and Zoubida, Meursault and Moussa both stood by the person they knew and harmed the one they did not know. There is no reason to think that Moussa would have cared to avenge a stranger or that Meursault would have refused to help a female neighbor who approached him. Whatever the merits of this particular case, a sense of honor that always demands vengeance for the women one loves can be just as myopic-and hence just as far from solidarity with one's fellows - as a willingness to help one's neighbors, even if what they request is wrong. Haroun offers an act of solidarity that harms no one by granting the Arab woman a name-again in contrast to Meursault-but although naming her (even if inaccurately) affirms her humanity, it is a limited gesture. Our ability to be in solidarity with others is often limited, and it is all too easy to mistake undiscerningly helping those we know for true solidarity. 
Haroun's relationship to his mother also shows how difficult the question of solidarity can be. He affirms that he loved her: "L'ai-je aimée? Bien sûr. Chez nous, la mère est la moitié du monde. Mais je ne lui ai jamais pardonné sa façon de me traiter." 27 The murder of Moussa poisoned their relationship, as she wanted him to fill the place of his older brother. As he explains, "Je te l'ai déjà dit, le corps de Moussa ne fut jamais retrouvé. Ma mère, par conséquent, m'imposa un strict devoir de réincarnation," 28 and he naturally resents her attempt to turn him into his brother. Haroun has no clear answer to the question of what it means to live in solidarity with someone he loves who has wronged him.

Daoud further complicates the question of solidarity with an allusion to Camus's La Peste: Haroun reflects, "J'aime Oran la nuit, malgré la prolifération des rats et tous ces immeubles sales insalubres qu'on repeint sans cesse; à cette heure, on dirait que les gens ont droit à quelque chose de plus que leur routine." 29 Oran is the city in which La Peste takes place, and rats carry the plague that strikes it. ${ }^{30}$ Haroun's reflections thus call to mind, for readers of Camus, a situation in which the nature of solidarity seems clear: when there is a plague, one must fight it. Yet in Haroun's Oran, there is no physical plague to combat and thus no evident way to act on the sentiment of solidarity that he feels at night. Not only is it unclear how he can live in solidarity with his mother, there is no final answer to the question of what exactly it is to live in solidarity with anyone at all-a point the rest of Daoud's novel will reinforce.

Eventually, Haroun offers a second account of what happened at the beach:

Arabe, je ne me suis jamais senti Arabe, tu sais. C'est comme la négritude qui n'existe que par le regard du Blanc. Dans le quartier, dans notre monde, on était musulman, on avait un prénom, un visage et des habitudes. Point. Eux étaient les 'étrangers,' les roumis que Dieu avait fait venir pour nous mettre à l'épreuve, mais dont les heures étaient de toute façon comptées: il partirait un jour ou l'autre, c'était certain. [...] Ton écrivain meurtrier s'est trompé, mon frère et son compagnon n'avaient pas du tout l'intention de le tuer, lui ou son ami barbeau. Ils attendaient seulement. Qu'ils partent tous, lui, le maquereau et les milliers d'autres. ${ }^{31}$

According to this version of the story, it was not a question of a "règlement de comptes," and Moussa was not on the beach to "donn[er] une correction à ton héros." 32 Meursault simply killed a man who was waiting for the colonizers to leave and then labeled him with the identity - "Arab" - that the colonizers imposed on the colonized. The woman (Zoubida) no longer appears in this account, which is simply a story of colonial injustice. But the fact that Haroun is offering two versions of the story, one in which Moussa wanted to avenge a woman's honor and one in which he was only waiting, 
indicates that the facts are not what is most important. As Lia Brozgal observes, "Haroun is less interested in representing the 'facts' of Moussa's death and more concerned with the meta-story, or the conventions of the story's narration: when it is recounted, by whom, and to what effect." 33 Haroun criticizes Meursault's colonialist manner of telling the story, in which his failure of solidarity becomes insignificant beside his refusal to do what is expected of him in a society that flees from the absurd. Whatever really happened at the beach, Meursault wrote about the murder he committed yet paid minimal attention to his victim and focused egotistically on his own confrontation with society.

\section{Murder and the Need for Solidarity}

But Haroun too has killed, and he finally tells the story in which he resembles Meursault. He explains that the murder occurred after he and M'ma moved into the house previously owned by M'ma's French employers, the Larquais family, who fled because of Algeria's war for independence. ${ }^{34}$ Haroun and his mother found a Frenchman who was hiding, ${ }^{35}$ and the presence of $\mathrm{M}^{\prime}$ ma, who desired revenge for the death of her son, compelled Haroun to kill him: “Mais M'ma était là, m'interdisant toute dérobade et exigeant ce qu'elle ne pouvait obtenir de ses propres mains: la vengeance." 36 He shoots the Frenchman at two in the morning, just as Meursault killed Moussa at two in the afternoon. ${ }^{37}$ In a deliberate contrast to Meursault's statement that the four bullets he fired into the Arab's corpse were "comme quatre coups brefs que je frappais sur la porte du malheur," 38 Haroun states that the two bullets with which he killed the Frenchman were “comme deux coups brefs frappés à la porte de la délivrance. C'est du moins ce que je crus ressentir." 39 Through this murder, he will realize the importance of solidarity, but as he implies, it is not truly a deliverance but is an act that isolates him from others.

Unlike Meursault, Haroun does state the name of his victim: Joseph. ${ }^{40}$ He also explicitly considers the significance of murder, observing, "Ton héros l'a bien compris, le meurtre est la seule bonne question que doit se poser un philosophe. Tout le reste est bavardage." 41 This statement is a clear allusion to a line from Camus's Le Mythe de Sisyphe, but in fact the relevant line is about suicide, not murder: "Il n'y a qu'un problème philosophique vraiment sérieux: c'est le suicide." 42 Haroun's statement draws not only on that line from Le Mythe de Sisyphe but also on L'Homme révolté, in which Camus asserts that "[n] ous ne saurons rien tant que nous ne saurons pas si nous avons le droit de tuer cet autre devant nous ou de consentir qu'il soit tué."43 Thus with Meursault, contre-enquête, Daoud emphasizes the othercentered question posed by the later Camus even as he most clearly references the comparatively self-centered phrase of the earlier book. This conflation of the questions posed in Le Mythe de Sisyphe and L'Homme révolté 
is in keeping with the spirit of Camus's work, as he concludes in L'Homme révolté that "[d]ès l'instant où ce bien [la vie] est reconnu comme tel, il est celui de tous les hommes. On ne peut donner une cohérence au meurtre si on la refuse au suicide." 44 For the later Camus, then, the refusal of suicide is equally the refusal of murder, and one who cares for his own life must care for that of others. By beginning not with the self and suicide but with the other and murder, Haroun emphasizes the question of solidarity (though he does so implicitly, as he never uses the word), whereas Le Mythe de Sisyphe does not.

Daoud's narrator thereby goes beyond Camus's initial philosophy of the absurd, but in a manner consistent with Camus's L'Homme révolté, in which Camus calls us to move beyond merely recogizing the absurd by actively revolting against it. As Camus acknowledges, the recognition of the absurd does not suffice to reject murder because it leaves murder both unacceptable and meaningless:

Le raisonnement absurde ne peut à la fois préserver la vie de celui qui parle et accepter le sacrifice des autres. [...] Ainsi, la même notion qui nous laissait croire que le meurtre était indifférent lui ôte ensuite ses justifications [...]. Pratiquement, un tel raisonnement nous assure en même temps qu'on peut et qu'on ne peut pas tuer. Il nous abandonne dans la contradiction [...]. ${ }^{45}$

It is only the revolt against the absurd that leads to the refusal of murder. As Camus explains, "Je crie que je ne crois à rien et que tout est absurde, mais je ne puis douter de mon cri et il me faut au moins croire à ma protestation. La première et la seule évidence qui me soit ainsi donnée, à l'intérieur de l'existence absurde, est la révolte."46 Once one has chosen to revolt - to live as if life had meaning-one sees that one must revolt on behalf of all people: I cannot cry out against the absurd solely for my own sake, for there is no way to justify refusing the absurd on my own account while siding with the universe insofar as it disregards others' desire to live. If I insist on living as if my life had meaning, I must live as though everyone's life had meaning. Camus asserts, "Je me révolte, donc nous sommes," 47 for all of humanity is bound together in my revolt. Whatever others choose, if I revolt, it is necessarily for them also, not only for myself.

Ironically, it is not through an initial revolt but through his act of murder that Haroun realizes that there are only two coherent possibilities: either one sides with the universe and treats all lives, without exception, as worthless, thereby betraying the protest against the absurd, or else one revolts and treats all lives, without exception, as valuable. Haroun explains,

Quand j'ai tué, donc, ce n'est pas l'innocence qui, par la suite, m'a le plus manqué, mais cette frontière qui existait jusque-là entre la vie et le crime. C'est un tracé difficile à rétablir ensuite. L'Autre est une mesure que l'on perd quand on tue. Souvent, depuis, j'ai 
ressenti un vertige incroyable, presque divin, à vouloir - du moins dans mes rêveries - tout résoudre, en quelque sorte, par l'assassinat. [...] Un certain goût pour la paresse s'installe chez le meurtrier impuni. Mais quelque chose d'irréparable aussi: le crime compromet pour toujours l'amour et la possibilité d'aimer. J'ai tué et, depuis, la vie n'est plus sacrée à mes yeux. [...] D'ailleurs, mon cher ami, le seul verset du Coran qui résonne en moi est bien celuici: 'Si vous tuez une seule âme, c'est comme si vous aviez tué l'humanité entière.'48

Thus Haroun comes to understand solidarity in reverse, by violating it rather than by choosing it. He understands that murder is an assault on all of humanity, a realization that accords with Camus's point that the révolté must value the life of all men. By committing a murder and thereby siding with the universe that does not grant meaning to any human life, Haroun has isolated himself from the human race. As Camus observes, "[s]i ce monde n'a pas de sens supérieur, si l'homme n'a que l'homme pour répondant, il suffit qu'un homme retranche un seul être de la société des vivants pour s'en exclure lui-même." 49 Yet at the same time, others are even farther from solidarity than Haroun is, for those who arrest him are, as in Meursault's case, concerned not with the murder but with a comparatively trivial detail. Daoud thus skillfully portrays a character who is doubly isolated: first because he violated solidarity, and second because he understands solidarity and the absurd better than many others.

The army officer who interrogates him focuses on the fact that Haroun killed the Frenchman shortly after the war for independence was over, not during the war. Haroun observes, “Je savais que je n'étais pas là pour avoir commis un meurtre mais pour ne pas l'avoir fait au bon moment." 50 Had he killed the Frenchman before Independence, the killing would have been acceptable; only because he did so after Independence is it a problem. As the officer tells him, "Le Français, il fallait le tuer avec nous, pendant la guerre, pas cette semaine!"51 Unlike Meursault, however, Haroun is released:

On allait me libérer sans explication, alors que je voulais être condamné. Je voulais qu'on me débarrasse de cette ombre pesante qui transformait ma vie en ténèbres. Il y avait même quelque chose d'injuste à me relâcher ainsi, sans m'expliquer si j'étais un criminel, un assassin, un mort, une victime, ou simplement un idiot indiscipliné. [...] J'avais tué et cela me donnait un vertige incroyable. Or personne n'y trouvait fondamentalement à redire. Seul l'horaire semblait poser un vague problème. [...] La gratuité de la mort de Moussa était inadmissible. Or ma vengeance venait d'être frappée de la même nullité!52

Condemnation would be preferable to this release "sans explication," for condemnation would at least confer meaning on his act. Instead, he finds 
himself confronted with the absurd: the indifference of others forces him to acknowledge that the murder he committed has no objective meaning. The universe offers no transcendent ground on which to base the decision to value life, and it is therefore at odds with the human desire that life be worth something. As he confers a significance on his act of murder, Haroun is in fact closer to solidarity than are those who release him: he at least realizes that he sided with the universe over his fellows, but the others do not understand that there is even a conflict. They simply do not care about the murder of Joseph Larquais, thus betraying humanity by passively accepting the refusal of man's desire that life have value. In contrast, Haroun does care even though he has no transcendent reason to do so.

One might object that Haroun's interrogators are acting rationally: a revolution requires discipline lest it degenerate into uncontrolled killing, so it is reasonable to set limits on when people may kill, but as Haroun did kill a colonial oppressor, he is not an ordinary murderer. A full examination of how the fight against oppressors can accord with solidarity is beyond the scope of this paper; suffice it to note that in truth, Haroun's killing of Joseph does not fit the ready narrative of the oppressed killing the oppressors. As Haroun states (before recounting his interrogation), " $\mathrm{M}^{\prime}$ ma savait pourquoi elle avait tué et elle était la seule à le savoir! Ni moi, ni Moussa, ni Joseph n'étions concernés par sa certitude."53 By maintaining abstract moral certainties that establish Joseph's death as a meaningful vengeance even though they do not help the Algerians, M'ma has taken refuge from the absurd that Haroun now confronts. The murder that she pushed him to commit did not avenge Moussa or aid in the establishment of justice, and it would not have done so even if it had by chance occurred before Independence. Moreover, if Haroun's interrogators believed that there must be no killings after Independence in order to protect life as much as possible while still overthrowing oppressors, they would at least declare Haroun "un idiot indiscipliné." Rather, they do not care about human life and do not want a murdered Frenchman after Independence simply because that does not fit their narrative. But as they do not want to punish Haroun, they reduce the murder to nothing: it receives no official acknowledgement, and Haroun is left alone with the knowledge that he has violated solidarity.

\section{Prophets Without God}

Eventually, Haroun discovers Meursault's novel thanks to Meriem, a young woman who sought out "the Arab's" family because she is writing her thesis on the book. ${ }^{54}$ He falls in love with her, but she eventually leaves; he explains that "elle s'est contentée d'aimer mon chagrin [...]." 55 Recall also his claim that "le crime compromet pour toujours l'amour et la possibilité d'aimer." 56 Overshadowed by the murder of Moussa and further isolated by his own murder of Joseph, Haroun cannot but lose the woman he loves. He 
adds, "Depuis, je trahis méthodiquement les femmes et réserve le meilleur de moi-même aux séparations." 57 Though the importance of solidarity is a theme implicit in his narrative, Haroun, who in addition to having killed admits to habitually betraying his lovers, has not found a way to live in solidarity with others.

When he reads Meursault's book, he is angered by the failure to acknowledge his brother - remembering reading the book for the first time, he exclaims, "Il y avait tout sauf l'essentiel: le nom de Moussa!"58 - yet he finds that he resembles this man who also killed. He states, "Cet homme, ton écrivain, semblait m'avoir volé mon jumeau, Zoudj, mon portrait, et même les détails de ma vie et les souvenirs de mon interrogatoire! C'était une plaisanterie parfaite. J'y cherchais des traces de mon frère, j'y retrouvais mon reflet, me découvrant presque sosie du meurtrier."59 In his brother's killer, he recognizes himself, for he too has committed a senseless crime and found himself a stranger to the society in which he lives. Commenting on the last lines of L'Étranger - "Pour que tout soit consommé, pour que je me sente moins seul, il me restait à souhaiter qu'il y ait beaucoup de spectateurs le jour de mon exécution et qu'ils m'accueillent avec des cris de haine" 60 Haroun declares,

Il y avait eu beaucoup de spectateurs, certes, mais pour son crime, pas pour son procès. Et quels spectateurs! Inconditionnels, idolâtres! Il n'y avait jamais eu des cris de haine parmi cette foule d'admirateurs. Ces dernières lignes m'avaient bouleversé. Un chefd'œuvre, l'ami. Un miroir tendu à mon âme et à ce que j'allais devenir dans ce pays, entre Allah et l'ennui. ${ }^{61}$

In Meursault's final wish, Haroun sees his own fate: he will remain a stranger in a country that flees the absurd in religion, and he will be hated if he proclaims the reality of the absurd. As he observed earlier in his narrative,

Le vendredi? Ce n'est pas un jour où Dieu s'est reposé, c'est un jour où il a décidé de fuir et de ne plus jamais revenir. Je le sais à ce son creux qui persiste après la prière des hommes, à leurs visages collés contre la vitre de la supplication. Et à leur teint de gens qui répondent à la peur de l'absurde par le zèle. ${ }^{62}$

For Haroun as for Meursault, mankind is alone in a world with no God who could ground meaning, and this realization sets Haroun apart from the Muslim majority in Algeria, just as Meursault was isolated from the Christian French. Moreover, as his account of his interrogation reveals, Haroun is isolated in that he accords significance to murder. Those who proclaim objective values grounded in religion ultimately care less for human life than Haroun, the murderer who acknowledges the absurd. 
In treating murder as significant, Haroun is not as far from Meursault as it might seem. Of all the characters in L'Étranger, it is in fact Meursault who best understands the significance of murder. Consider his reaction to his murder of the Arab:

J'ai compris que j'avais détruit l'équilibre du jour, le silence exceptionnel d'une plage où j'avais été heureux. Alors, j'ai tiré encore quatre fois sur un corps inerte où les balles s'enfonçaient sans qu'il y parût. Et c'était comme quatre coups brefs que je frappais sur la porte du malheur. ${ }^{63}$

Meursault is in fact the only one who realizes - however inadequately - that he has killed a human being. Once he has committed the murder, nothing else matters; he has committed an act of destruction, and he might as well shoot the corpse, for it does not matter to the murdered man whether his killer treats the body in a civilized way. Later, the juge d'instruction asks him, "'Pourquoi, pourquoi avez-vous tiré sur un corps à terre?'"64 thus focusing not on the murder itself but on the uncivilized action Meursault took afterward. When he finally acknowledges the murder, he does not even call it a murder: "Il m'a seulement demandé du même air un peu las si je regrettais mon acte. J'ai réfléchi et j'ai dit que plutôt que du regret véritable, j'éprouvais un certain ennui." 65 To the juge d'instruction, the murder is simply an act, not the violent end of a man's life. Meursault, who does not even regret the murder, at least realized that it matters more than the bullets he fired at the dead body. Moreover, at the trial, he is finally condemned not for the murder but for his apparent indifference to his mother's death: as the prosecutor declares, "'[J]'accuse cet homme d'avoir enterré sa mère avec un cœur de criminel.'"66 Meursault's feeble explanation-"j'ai dit, un peu au hasard, d'ailleurs, que je n'avais pas l'intention de tuer l'Arabe" 67 -fails to convince the jury to acquit him not because he acted as if he meant to kill the Arab or because it is wrong to kill even unintentionally but because no one cares about the dead Arab. Meursault is no révolté who calls for solidarity, and his excuse for the murder is poor, but he at least focuses on his real crime. As far from solidarity as he is, he is closer to it than are those who condemn him for his behavior at his mother's funeral.

Even if Meursault had preached solidarity, we could not turn to him for rules telling us how to live, for there are none. Several times throughout his narrative, Haroun has mentioned a man he refers to as "'le fantôme de la bouteille'" who "vient presque tous les jours ici [au bar]" 68 and has "l'air intelligent mais en rupture avec les certitudes de son époque," 69 and whom he describes as "mon double."70 Near the end of the novel, when he insists on speaking to the "phantom" to satisfy the curiosity of his unnamed interlocutor, he notices that the "phantom" "[a] l'air des origines latines [...]" and finds that he is "un sourd-muet apparrement tuberculeux [...]."71 The "phantom" is evidently an allusion to Camus himself, as his mother had Spanish ancestry and was deaf (and mute, according to some), ${ }^{72}$ and Camus 
had tuberculosis. ${ }^{73}$ Camus and Haroun both reject the false certainties to which people flee in an attempt to escape the absurd, but it is Haroun who speaks now, and Camus must be silent. The "phantom's" silence reminds us that looking to Camus for final answers would be foolish, for although Camus was a great writer and thinker, no one can offer certainty and meaning. There is no rule that tells us what actions solidarity requires, and we are left to make our own way in the world, working out for ourselves what it means to live in solidarity with others.

It is important to note that Haroun's story is in no way a justification of colonialism. Certainly the French colonizers violated solidarity, as did Meursault when he killed Moussa. But as I argued above, Haroun's murder does not fit the narrative of the colonized overthrowing the colonizers.

Moreover, any narrative that forgets the need for solidarity in the face of the absurd fails to address the situation of post-Independence Algeria. It is not that Algeria should not have become independent but that now that it is, its people must decide what it means to live in solidarity with each other in a nation still overshadowed by colonialism and revolution. Camus's appearance as a deaf-mute is also significant in that he must cede the floor to a contemporary Algerian who can address the problems of postIndependence Algeria. ${ }^{74}$ But far from silencing Camus (who does appear, recall, as Haroun's "double"), Daoud elaborates on and revitalizes Camus's call for solidarity in a new context: that of Algeria after the war. Haroun observes, “J'ai vu se consumer l'enthousiasme de l'Indépendance, s'échouer les illusions [...]."75 French colonialism was unjust, for the colonizers sided with a universe devoid of meaning in which human life has no objective value, but although Algeria has entered a postcolonial era, the universe remains. Daoud's novel is a call (one that is at the same time universal and addressed to his countrymen) to grapple with that reality instead of escaping into the abstract certainties of M'ma or of naïve believers who see their God chiefly as a ground for objective truth. Crying out to his interlocutor against the flight from the absurd that plagues his country, Haroun recounts that he once confronted an imam with the same words that Meursault used against the priest ${ }^{76}$ and proclaims,

C'est une seule phrase que personne ne comprend: 'Il n'y a personne ici! Il n'y a jamais eu personne! La mosquée est vide, le minaret est vide. C'est le vide!' C'est sûr, il y aura beaucoup de spectateurs le jour de mon exécution et ils m'accueilleront avec des cris de haine. Ton héros avait peut-être raison dès le début: il n'y a jamais eu aucun survivant dans cette histoire. Tout le monde est mort dans un seul coup, en une seule fois. ${ }^{77}$

Meursault and Haroun are two murderers opposing the flight from the absurd-and while, as I noted above, Haroun's criticism of Meursault suggests that Meursault has no right to be admired as a prophet with insight 
into the absurd, unworthy prophets are the best we can hope for, as there is no transcendent standard by which we can justify ourselves, and even those who are not murderers have been bystanders to oppression. There are no survivors, and none are innocent.

Nearing the end of his story, Haroun says, "Juste une dernière blague de mon cru. Tu sais comment on prononce Meursault en arabe? Non? ElMerssoul. 'L'envoyé' ou 'le messager.' Pas mal, non?"78 If Meursault was a messenger, it does not follow that he was admirable. Recall Haroun's description of Meursault's admirers as "[i]nconditionnels, idolâtres!"79 It is ironic that the people to whom he was a stranger admire him now, and blind admiration overlooks the wrongs he committed, but we can still learn from his narrative. Camus wrote of Meursault, "Il m'est arrivé de dire aussi, et toujours paradoxalement, que j'avais essayé de figurer dans mon personnage le seul christ que nous méritions." 80 Meursault is no savior, but he is a prophet without God whose story can awaken us to the absurd and even to the need for solidarity, provided we do not ourselves violate solidarity by admiring him to the point of forgetting that he was a murderer. If we remember the murder yet respond to his awareness of the absurd, we can perhaps go beyond him by finding a way to live in solidarity with others.

Meursault is not the only prophet of the absurd. "Moussa" is the name in Arabic of Moses, an important prophet in Islam, 81 and Haroun is the name in Arabic of Aaron, Moses' brother, who according to the Quran was also a prophet. 82 The Quran states that when God sent Moses to confront Pharaoh, Moses requested that Aaron help him: “And my brother Aaron $\mathrm{He}$ is more eloquent in speech than I: so send him with me as a helper, to confirm (and strengthen) me: for I fear that they may accuse me of falsehood." 83 Haroun finds himself speaking for Moussa-not as a helper and not as one sent by God, but as the only one left to speak for him in a world with no God. Moreover, Haroun calls everyone Moussa: "Les gens de ce pays ont l'habitude d'appeler tous les inconnus 'Mohammed,' moi je donne à tous le prénom de 'Moussa.'"84 If everyone is Moussa, then everyone finds himself in the situation of being a prophet without God - and if everyone is Moussa, rather than Mohammed, then Haroun is speaking for everyone. Although we are all abandoned prophets who, if we speak truly, can never prophesy the coming of a savior or receive a word from God, perhaps we need not be prophets who work alone. To speak for and with others is already a gesture of solidarity, though people who are fleeing the absurd might meet it with anger.

\section{Conclusion}

Finally, Haroun asks, 
Mon histoire te convient-elle? C'est tout ce que je peux t'offrir. C'est ma parole, à prendre ou à laisser. Je suis le frère de Moussa ou le frère de personne. Juste un mythomane que tu as rencontré pour remplir tes cahiers... C'est ton choix, l'ami. [...] Deux inconnus avec deux histoires sur une plage sans fin. Laquelle est la plus vrai? Une question intime. À toi de trancher. 85

Thus he leaves his interlocutor - and the reader - to decide whether his story is true. More importantly, he leaves the reader to decide how to respond to the absurd and how to attempt to live in solidarity with others. Certainly we have no way of determining whether Haroun has told the truth about himself, but the force of his story does not lie in the degree to which it corresponds to the facts. Rather, his narrative is important because it reminds us that we must work out for ourselves what solidarity is. Were he a wholly admirable narrator, we might think that his life offers certain answers, but as he is not, we are forced to realize that no one at all can offer final, certain rules for solidarity, as there is no transcendent reality in which such rules could find their ground. Solidarity can only occur in concrete situations with concrete people, for it requires that we acknowledge the absurd and thus can have nothing to do with the transcendent absolutes to which people turn when they flee the absurd.

Haroun concludes by alluding to Meursault's conclusion to L'Étranger: "Je voudrais, moi aussi, qu'il soit nombreux, mes spectateurs, et que leur haine soit sauvage." 86 In a world in which people flee the absurd, simply proclaiming the absurd - as Haroun and Meursault have both done - can be an act of solidarity, for if people face the absurd, they may go farther than the mere acknowledgment of the absurd by seeking solidarity in their turn. But there is no guarantee that they will come to acknowledge the absurd, and it is more likely that they will respond to such an attempt at solidarity with hatred. The genius of Daoud's novel is that it reminds us of the need to live in solidarity with others while at the same time compelling us to realize both that it is unclear how to do so when others do not desire solidarity and that there is no final answer telling us how to proceed. Those who flee the absurd may hate those who seek solidarity, but we must seek to live in solidarity with others even if that means facing their hatred.

1 The political aspects of Daoud's novel also merit attention, but they are beyond the scope of this paper. For a discussion of the place of Meursault, contre-enquête in contemporary Algerian debates, see Adam Shatz, "Stranger Still," The New York Times, April 1, 2015, http://nyti.ms/1Dt2Dzc, accessed August 1, 2016. For a scholarly examination of the novel that includes a discussion of its reception, see Alice Kaplan, "Making L'Étranger Contemporary: Kamel Daoud's Meursault, contre-enquête," in Being Contemporary: French Literature, Culture 
and Politics Today, ed. by Lia Brozgal and Sara Kippur (Liverpool: Liverpool University Press, 2016), 34-346.

2 Kamel Daoud, Meursault, contre-enquête (Paris: Actes Sud, 2014), 146.

3 Ibid., 137. Alice Kaplan notes that in the original 2013 Algerian edition of Meursault, contreenquête, the title of Meursault's book was L'Étranger; it was changed to L'Autre for the 2014 French edition. (Alice Kaplan, “'Meursault, contre-enquête' de Kamel Daoud," Contreligne, June 2014, http://www.contreligne.eu/2014/06/kamel-daoud-meursault-contre-enquete/, accessed August 1, 2016.

${ }^{4}$ Haroun states that after reading L'Autre with him, “[Meriem] m'offrit les autres livres écrits par cet homme [...]." (Daoud, Meursault, contre-enquête, 142.)

${ }^{5}$ Daoud, Meursault, contre-enquête, 1.

${ }^{6}$ Albert Camus, L’Étranger (Paris: Gallimard, 2007), 7.

${ }^{7}$ Albert Camus, Le Mythe de Sisyphe: Essai sur l'absurde (Paris: Gallimard, 1942), 46.

8 Ibid., 79-80.

${ }^{9}$ Albert Camus, L'Homme révolté (Paris: Gallimard, 1951), 23.

10 Ibid., 37.

11 Daoud, Meursault, contre-enquête, 13.

12 Ibid., 13-14.

13 Ibid., 14.

14 Ibid., 16.

${ }^{15}$ Camus, L'Étranger, 35.

16 Ibid., 36.

17 Ibid., 42.

18 Ibid., 58.

19 Ibid., 45.

20 Ibid., 59.

21 Ibid., 61.

22 Ibid., 61.

23 Ibid., 61-64.

${ }^{24}$ Daoud, Meursault, contre-enquête, 17.

25 Ibid., 29.

26 Ibid., 30.

27 Daoud, Meursault, contre-enquête, 46.

28 Ibid., 51. 
29 Ibid., 59.

30 See Albert Camus, La Peste (Paris: Gallimard, 1947), 1 and 62.

31 Daoud, Meursault, contre-enquête, 70.

32 Ibid., 29.

33 Lia Brozgal, "The Critical Pulse of the Contre-Enquête: Kamel Daoud on the Maghrebi Novel in French," Contemporary French and Francophone Studies 20.1 (2016): 41.

${ }^{34}$ Daoud, Meursault, contre-enquête, 90.

35 Ibid., 93.

36 Ibid., 94.

37 Ibid., 89.

38 Camus, L'Étranger, 64.

39 Daoud, Meursault, contre-enquête, 95.

${ }^{40}$ Daoud, Meursault, contre-enquête, 98. His full name is Joseph Larquais (ibid., 118).

41 lbid., 99.

${ }^{42}$ Camus, Le Mythe de Sisyphe, 17.

${ }^{43}$ Camus, L'Homme révolté, 16.

44 Ibid., 19.

45 Camus, L'Homme révolté, 20.

46 Ibid., 23.

47 Ibid., 38.

${ }^{48}$ Daoud, Meursault, contre-enquête, 100-101.

${ }^{49}$ Camus, L'Homme révolté, 351-352.

${ }^{50}$ Daoud, Meursault, contre-enquête, 117.

51 Ibid., 119.

52 Ibid., 121.

${ }^{53}$ Daoud, Meursault, contre-enquête, 107.

${ }^{54}$ Daoud, Meursault, contre-enquête, 137.

55 lbid., 143.

56 Ibid., 101.

57 Ibid., 143.

${ }^{58}$ Daoud, Meursault, contre-enquête, 140.

${ }^{59}$ Ibid., 141. 


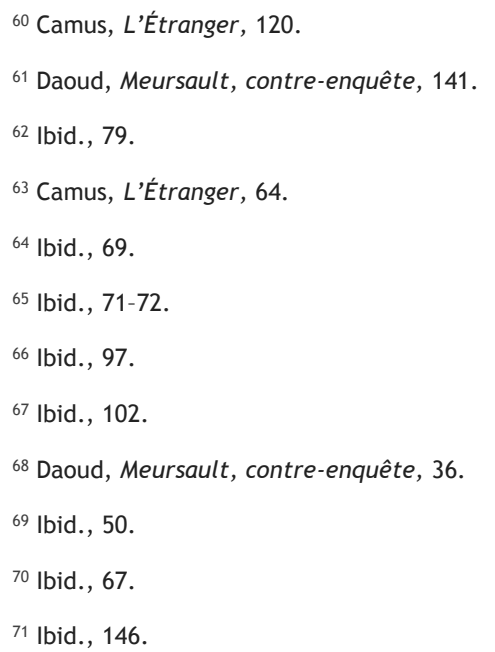

72 See Olivier Todd, Albert Camus: Une vie. (Paris: Gallimard, 1996), 24.

73 See ibid., 45.

${ }^{74} \mathrm{I}$ am eliding the question of whether Camus was Algerian because Haroun dismisses this debate as it applies to Meursault in the world of the novel: "Le pire, c'est quand les meutes de chiens de lune ont commencé à se battre et se déchirer pour savoir si ton héros avait ma nationalité ou celle de ses voisins d'immeuble. [...] On [...] désignait [Moussa] comme l'Arabe, même chez les Arabes. C'est une nationalité, “Arabe,” dis-moi?” (Daoud, Meursault, contre-enquête, 148). Meursault, contre-enquête thus portrays the debate over the nationality of Meursault/Camus as irrelevant to the problems of contemporary Algeria and even to the question of Algerian identity. It is not a question of rejecting Camus, who remains present as Daoud, through Haroun, adds new dimensions to existential literature and provides a narrative that Camus did not. For a more detailed discussion of Meursault, contre-enquête in relation to Algerian understandings of Camus, see Valérie K. Orlando, "Conversations with Camus as Foil, Foe and Fantasy in Contemporary Writing by Algierian Authors of French Expression," The Journal of North African Studies, 20.5 (2015): 865-863.

75 Daoud, Meursault, contre-enquête, 148.

76 Ibid., pp. 150-152; L'Étranger, 118-120.

77 Daoud, Meursault, contre-enquête, 152.

${ }^{78}$ Daoud, Meursault, contre-enquête, 153.

79 lbid., 141.

80 Albert Camus, “L'Étranger: Préface à l'édition universitaire américaine," in CEuvres: Albert Camus (Paris: Gallimard, 2013), 249.

81 Lia Brozgal also notes that "Moussa" is the Arabic form of "Moses." See Brozgal, "The Critical Pulse of the Contre-Enquête," 45, note 10.

82 Quran 19:53. 
83 Quran 28:34, trans. Yusuf Ali, http://www.islam101.com/quran/yusufAli, accessed August 3, 2016. The next verse states that God agreed to send Aaron with Moses.

${ }^{84}$ Daoud, Meursault, contre-enquête, 32.

${ }^{85}$ Daoud, Meursault, contre-enquête, 153.

${ }^{86}$ Daoud, Meursault, contre-enquête, 153. 